ARTICLE

\title{
Large mass-independent sulphur isotope anomalies link stratospheric volcanism to the Late Ordovician mass extinction
}

Dongping $\mathrm{Hu}^{1}$, Menghan $\mathrm{Li}^{1}$, Xiaolin Zhang ${ }^{1}$, Alexandra V. Turchyn (1) ${ }^{2}$, Yizhe Gong ${ }^{1}$ \& Yanan Shen (1) ${ }^{1 凶}$

Volcanic eruptions are thought to be a key driver of rapid climate perturbations over geological time, such as global cooling, global warming, and changes in ocean chemistry. However, identification of stratospheric volcanic eruptions in the geological record and their causal link to the mass extinction events during the past 540 million years remains challenging. Here we report unexpected, large mass-independent sulphur isotopic compositions of pyrite with $\Delta^{33} \mathrm{~S}$ of up to $0.91 \%$ in Late Ordovician sedimentary rocks from South China. The magnitude of the $\Delta^{33} \mathrm{~S}$ is similar to that discovered in ice core sulphate originating from stratospheric volcanism. The coincidence between the large $\Delta^{33} \mathrm{~S}$ and the first pulse of the Late Ordovician mass extinction about 445 million years ago suggests that stratospheric volcanic eruptions may have contributed to synergetic environmental deteriorations such as prolonged climatic perturbations and oceanic anoxia, related to the mass extinction.

\footnotetext{
${ }^{1}$ School of Earth and Space Sciences, University of Science and Technology of China, Hefei 230026, China. ${ }^{2}$ Department of Earth Sciences, University of

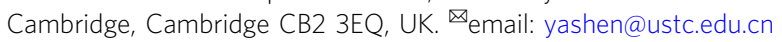


T he Late Ordovician mass extinction (LOME), which eliminated $\sim 85 \%$ of marine species globally, has been ranked as the second most severe Phanerozoic biotic crisis $^{1,2}$. The LOME occurred in two pulses, one at the beginning of the Hirnantian stage, corresponding to the lower N. extraordinarius Zone and the other at the base of the $N$. persculptus Zone of the uppermost Hirnantian ${ }^{1,2}$. Global cooling and habitat loss resulting from the waxing and waning of glaciers during the Hirnantian have been traditionally held to have caused the LOME $^{3,4}$. However, the cycles of glaciation and associated sealevel change during the Hirnantian likely were more complex than originally assumed ${ }^{5-8}$. Oceanic anoxia has been linked to the LOME $^{9-12}$, however, temporal changes in global redox conditions that could synchronise with each pulse of the LOME remains elusive. The emplacement of a large igneous province (LIP) also has been hypothesised as a driver for the LOME based on mercury $(\mathrm{Hg})$ enrichments ${ }^{13,14}$. However, the $\mathrm{Hg}$ enrichments in the sedimentary rocks of the Ordovician-Silurian boundary from South China have been argued to be sulphide-hosted rather than of volcanic origin, challenging the hypothesis of a volcanic driver for the LOME ${ }^{15}$. Here, we report sulphur isotope data $\left(\delta^{34} S, \Delta^{33} S\right.$ and $\Delta^{36}$ S) of pyrite from two sedimentary successions from South China, and we use a characteristic signal of large $\Delta^{33} S$ anomalies, resulting from stratospheric photochemical reactions ${ }^{16-20}$ to constrain the nature of volcanic eruptions during the Late Ordovician. Our results provide new evidence of linking stratospheric volcanic eruptions and environmental deterioration to the LOME.

\section{Sampling and results}

Geological setting and stratigraphy. Our samples were collected from the Honghuayuan section and a drill core (named XY5) in South China. The Honghuayuan section is a typical shallow-water section, which was deposited in an innermost sub-basin near the Dianqian uplift ${ }^{21,22}$ (Supplementary Fig. 1). To study isotopic changes along a paleoenvironmental gradient, we also collected the pristine core material of the deep-water section within XY5. The XY5 section was deposited near a slope setting with a likely water depth of ca. 100-200 $\mathrm{m}$ based on the assemblage of benthic invertebrate fossils ${ }^{23}$ (Supplementary Fig. 1). The OrdovicianSilurian strata in both successions consist of the Late Ordovician Wufeng Formation, Kuanyinchiao Bed and the earliest Silurian Lungmachi Formation (Fig. 1a, b). The Wufeng and Lungmachi formations are composed of black shales from which abundant and diverse graptolite fossils have been reported ${ }^{22}$. The Kuanyinchiao Bed is composed mainly of dark brown mudstone intercalated with thin carbonate lenses that preserve abundant shelly fossils. In both areas, numerous K-bentonite beds with thickness of $1-1.5 \mathrm{~cm}$ but many are $<3 \mathrm{~mm}$, have been found from $D$. complexus to upper $P$. pacificus Zone, indicate volcanic eruptions during the Late Ordovician in South China ${ }^{24,25}$ (Fig. 1a, b). The biostratigraphy of the two successions has been well established and they record the two pulses of the LOME that can be correlated regionally and globally ${ }^{22}$ (Fig. 1a, b).

Multiple sulphur isotope data. We measured quadruple Sisotope compositions $\left(\delta^{33} S, \delta^{34} S\right.$ and $\delta^{36} S$ ) of pyrite from the Honghuayuan section and the XY5 core. The multiple sulphur isotope data are reported using conventional delta notation: $\delta^{3 \times} S$ $=1000 \times\left(\left({ }^{3 \times S} /{ }^{32} S\right)_{\text {sample }}\left({ }^{3 x} S / 32 S\right)_{\text {reference }}-1\right)$, where $3 \mathrm{x}=33,34$, or 36. Capital delta notation is defined to describe relationships involving ${ }^{33} S$ and ${ }^{36} S:{ }^{33} S=\delta^{33} S-1000 \times\left(\left(1+\delta^{34} S / 1000\right)\right.$ $0.515-1), \quad \Delta^{36} S=\delta^{36} S-1000 \times\left(\left(1+\delta^{34} S / 1000\right)^{1.90}-1\right)$. The $\Delta^{33} S$ and $\Delta^{36} S$ are defined with exponents of 0.515 and 1.90 to approximate the deviation from single step low-temperature equilibrium exchange reactions ${ }^{26,27}$. Delta and capital delta values are given in unit of per mille (\%o). Figures 1-2 present $\delta^{34} S$ and $\Delta^{33} \mathrm{~S}$ data of pyrite from the studied successions (full analytical data of the samples and reference materials available as Supplementary Tables $1-3$ ).

At Honghuayuan, the $\delta^{34} S$ of pyrite ranges from $-9.1 \%$ to $4.2 \%$ in the Katian strata and is followed by a large positive excursion of $\sim 17 \%$ during the Hirnantian Stage (Fig. 1a). The $\delta^{34} S$ then returns to the pre-excursion baseline value in the Rhuddanian strata (Fig. 1a). Likewise, the $\delta^{34} S$ from Katian strata of the XY5 core varies between $-26.5 \%$ and $-1.7 \%$ and is followed by a large positive $\delta^{34} \mathrm{~S}$ excursion of $\sim 26 \%$ during the Hirnantian Stage (Fig. 1b). Higher in the stratigraphic section, the $\delta^{34} S$ of the pyrite returns to the pre-excursion sulphur isotope composition with a narrow range of $-21.4 \%$ to $-19.3 \%$ in the Rhuddanian strata (Fig. 1b).

At Honghuayuan, the $\Delta^{33} \mathrm{~S}$ data of the Wufeng Formation exhibit positive values varying between $0.46 \%$ and $0.91 \%$ with an average of $0.75 \%$ with $\Delta^{36} \mathrm{~S}$ values from $-0.28 \%$ to $0.11 \%$ (Fig. 1a; Supplementary Table 1). These unusually positive $\Delta^{33} S$ are similar in magnitude to the S-isotope mass-independent fractionation (S-MIF) data prior to the great oxidation event (GOE) about 2.3 Gyr ago (Fig. 2), which were likely produced by the photodissociation of S-bearing gases by short wavelength ultraviolet (UV) rays in an oxygen poor atmosphere ${ }^{27-32}$. Coincident with the disappearance of the K-bentonite beds, the S-MIF signals disappear and the $\Delta^{33} \mathrm{~S}$ varies little between $-0.02 \%$ and $0.22 \%$ for the rest of the Honghuayuan section with $\Delta^{36} \mathrm{~S}$ values ranging from $-1.03 \%$ to $0.06 \%$ (Fig. 1a; Supplementary Table 1). However, unlike the $\Delta^{33} S$ data from Honghuayuan, none of the XY5 core samples shows a signal of S-MIF; all pyrite samples from the XY5 core exhibit S-isotope mass-dependent fractionation (S-MDF) signals with the $\Delta^{33} \mathrm{~S}$ ranging from $0.04 \%$ to $0.16 \%$ with an average of $0.09 \%$, corresponding with $\Delta^{36} \mathrm{~S}$ values ranging from $-0.95 \%$ to $-0.18 \%$ (Fig. 1b; Supplementary Table 2).

\section{Discussion}

Origin of the sulphur isotope mass-independent fractionation signal. Almost all physical, chemical and biological processes fractionate S-isotopes by the relative mass differences of each isotope, producing $\Delta^{33} \mathrm{~S}$ values that are near-zero ${ }^{27}$. Sulphur photochemistry is one of the few processes that produces massindependent fractionation, yielding non-zero $\Delta^{33} S$ values ${ }^{16,29,30}$. As such, S-isotopes have been successfully used in polar snow and ice cores to distinguish between stratospheric and tropospheric volcanic eruptions ${ }^{16-20}$. In the stratosphere, at or above the ozone layer, the sulphur ejected from volcanic emissions will be exposed to UV radiation, acquiring a S-MIF signal with non-zero $\Delta^{33} \mathrm{~S}$ value ${ }^{16-20,29,30}$.

The $\Delta^{33} \mathrm{~S}$ data varying between $0.46 \%$ and $0.91 \%$ of the Wufeng Formation at Honghuayuan are far too large to be generated by S-MDF processes alone ${ }^{28,30,33}$. Two other possibilities could be considered; weathering input from Archean rocks that have a non-zero $\Delta^{33}$ S, and magnetic isotope effects (MIE) during thermochemical sulphate reduction (TSR). Weathering input of Archean-age sulphur minerals with S-MIF is an unlikely mechanism to produce the S-MIF signals we observe because the Precambrian basement of the inner Yangtze platform, which would comprise the rocks that could be weathered during the Late Ordovician, consists exclusively of Neoproterozoic lithologies younger than 850 million years ${ }^{34}$.

Experiments have shown that MIE during TSR can impart a non-zero S-MIF signature ${ }^{35,36}$; however, we suggest that this process is an unlikely source for our observation of S-MIF from 

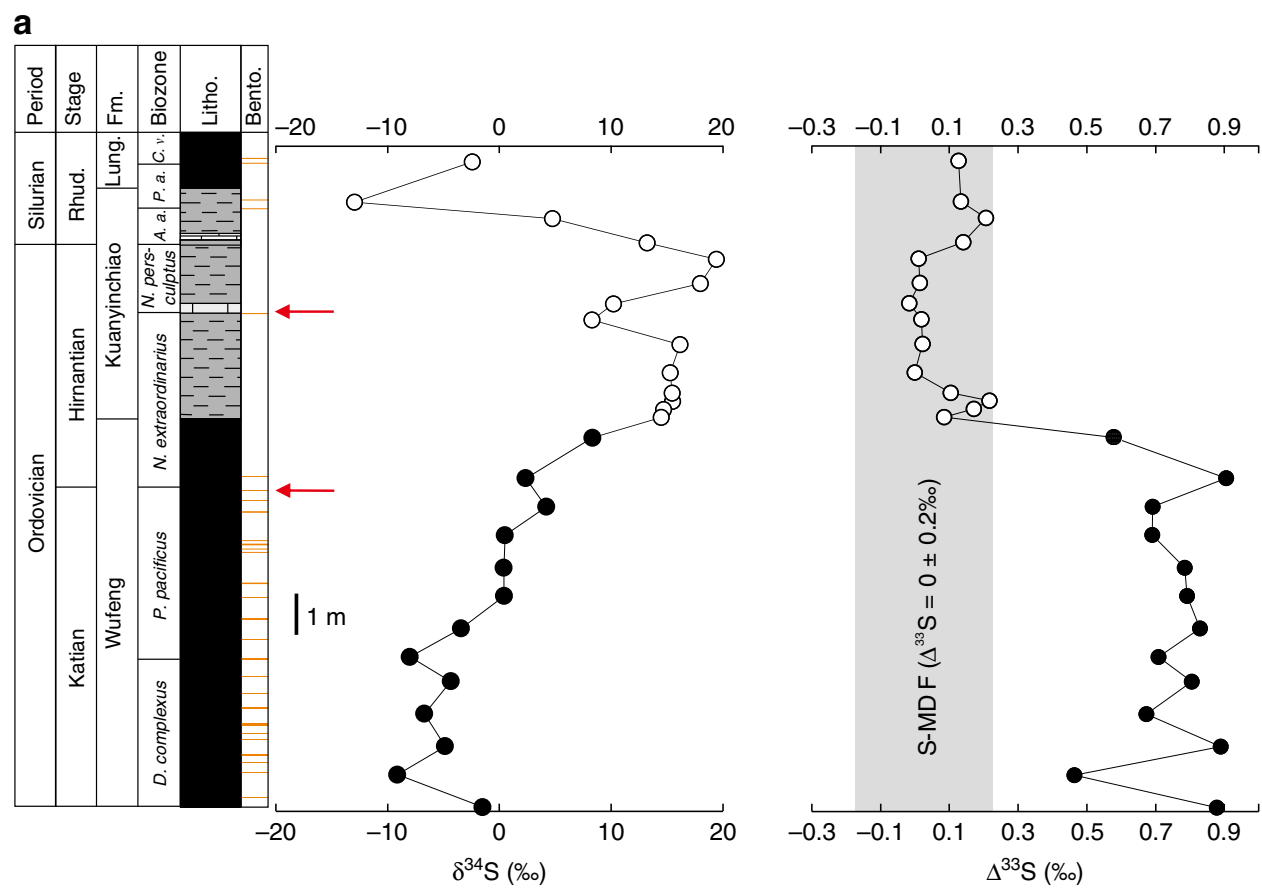

b

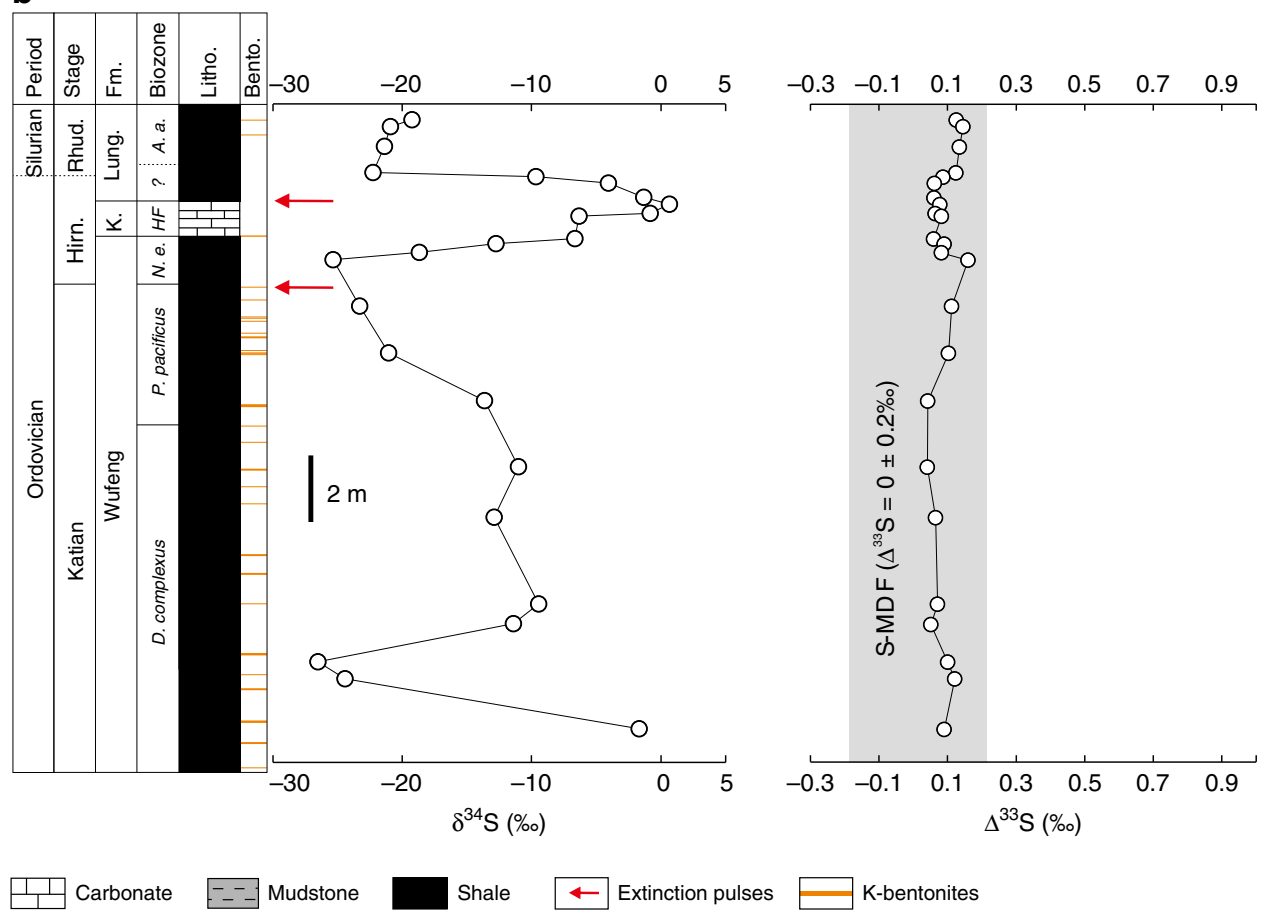

Fig. $1 \delta^{\mathbf{3 4}} \mathbf{S}$ and $\boldsymbol{\Delta}^{\mathbf{3 3}} \mathbf{S}$ data for the Honghuayuan and XY5 sections. a Honghuayuan section. $\mathbf{b} \mathrm{XY} 5$ core. K-bentonites are based on ref. ${ }^{24}$. Filled black circles indicate S-isotope mass-independent fractionation (S-MIF), and grey fields denote $\Delta^{33} \mathrm{~S}=0 \pm 0.2 \%$ o representing the traditional limit of S-isotope mass-dependent fractionation (S-MDF) ${ }^{27}$. Analytical errors are smaller than the symbol sizes for all data reported in this study. N.e.: Normalograptus extraordinarius, A.a.: Akidograptus ascensus, P.a.: Parakidograptus acuminatus, C.v.: Cystograptus vesiculosus, Lung.: Lungmachi, K.: Kuanyinchiao, Hirn.: Hirnantian, HF: Hirnantian Fauna, Rhud.: Rhuddanian, Fm.: Formation, Litho.: Lithology, Bento.: K-bentonites.

Honghuayuan. As shown in Fig. 3, a plot of $\delta^{34} S-\delta^{33} S$ for all pyrites that have a non-zero S-MIF at Honghuayuan follows a highly-correlated array: $\delta^{33} \mathrm{~S}=0.5174 \times \delta^{34} S+0.7461 \quad\left(R^{2}=\right.$ $0.9975, p<0.01, n=13)$. This array parallels the mass fractionation line (MFL), indicating that the mass-dependent process of microbial sulphate reduction (MSR), which would produce sulphide to form pyrite, started from a sulphate pool with a SMIF composition (Fig. 3). In contrast, experimentally produced
S-MIF by TSR often exhibits a scattered $\delta^{34} S-\delta^{33} \mathrm{~S}$, with little correlation $^{35,36}$ (Fig. 3). The equivalent vitrinite reflectance (Ro) for Honghuayuan samples is low with an average of $\sim 0.7 \%$ (Supplementary Table 4), implying that these sedimentary rocks are thermally immature and have had a maximum burial temperature $<110^{\circ} \mathrm{C}$ (estimated from the equation in ref. ${ }^{37}$ ), which is well below the minimum temperature for TSR in both experimental and natural conditions $\left(\sim 150^{\circ} \mathrm{C}^{35,36}\right.$ and $\sim 120^{\circ} \mathrm{C}^{38}$, 


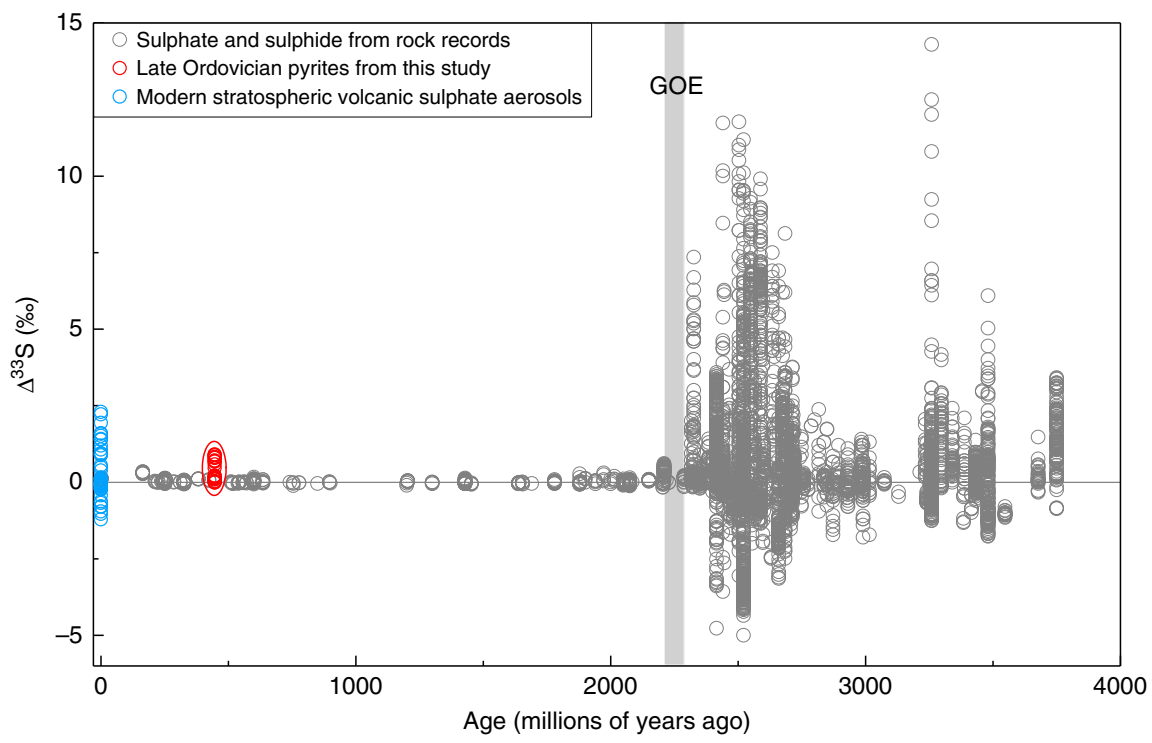

Fig. 2 Summary of $\Delta^{33} \mathbf{S}$ data over geological time. Data within the red oval are from this study, and the stratospheric volcanic sulphate data (blue circles) are from refs. 17,19,45,46, and the rock record data (grey circles) are compiled from refs. 27,28,30,31,44,47. GOE: Great Oxidation Event.

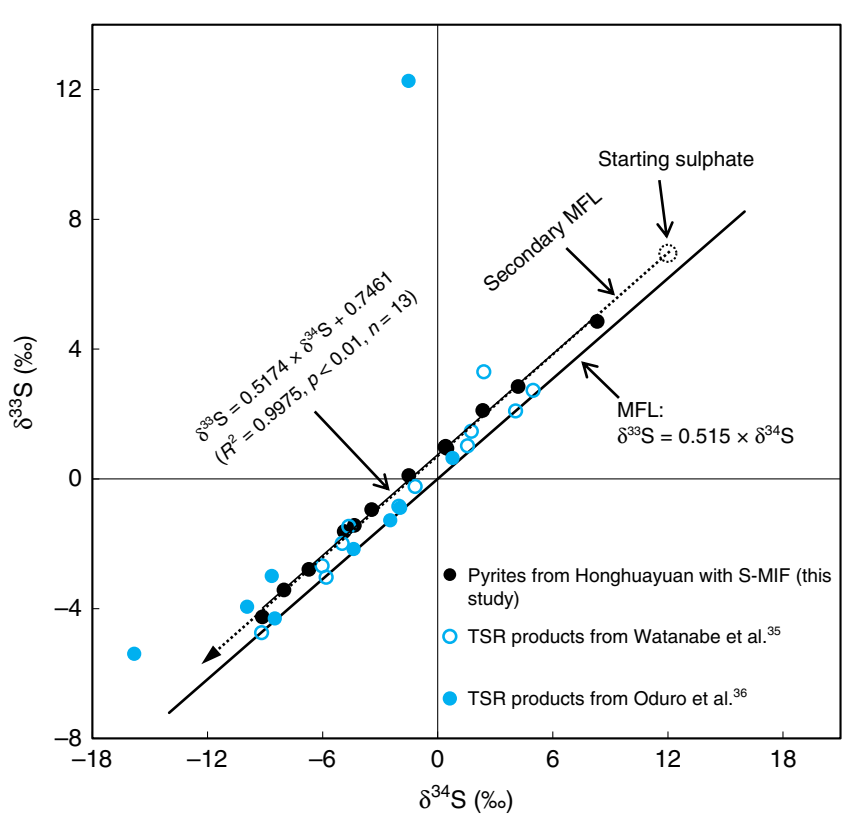

Fig. $3 \delta^{34} S$ and $\delta^{33} S$ for Honghuayuan and thermochemical sulphate reduction experiments. Filled black circles represent the S-MIF from Honghuayuan, and blue circles are the experimental data from refs. ${ }^{35,36}$ The dotted line illustrates the fractionation associated with microbial reduction of sulphate with a S-MIF composition (open dotted circle) that fits all pyrites with positive $\Delta^{33} S$ anomalies from Honghuayuan. MFL: mass fractionation line, S-MIF: S-isotope mass-independent fractionation, TSR: thermochemical sulphate reduction.

respectively). Therefore, the Ro data indicate that TSR could not have occurred in Honghuayuan samples we measured.

In addition, multiple S-isotope data from thermally mature oil shales and organic carbon-enriched sedimentary rocks with burial temperature higher than $200^{\circ} \mathrm{C}$ still show low $\delta^{34} \mathrm{~S}$ of pyrite or organic-bound sulphide with mass-dependent $\Delta^{33} \mathrm{~S}$ signals ranging from $-0.055 \%$ o to $0.073 \%$; these have been attributed to retain the sulphur isotopic composition acquired during MSR and/or microbial sulphur disproportionation ${ }^{39,40}$. Therefore, although these organic carbon-enriched and pyrite-bearing sedimentary rocks may have reached the temperature where TSR may occur, there is no isotopic evidence that TSR did occur and produce S-MIF signals. Moreover, sulphide produced by TSR in experimental or natural conditions routinely displays higher $\delta^{34} \mathrm{~S}$ similar to or same as that of the parent sulphate, because TSR can be quantitative in converting sulphate to sulphide ${ }^{41-43}$. In contrast, our S-MIF data from Honghuayuan show consistently lower $\delta^{34} \mathrm{~S}$ (Fig. 1a), further hinting at a bacteriogenic origin of the sulphide that then converted to pyrite.

We note that our S-MIF data show limited $\Delta^{36} \mathrm{~S}$ variation, which does not display a statistically distinct $\Delta^{36} S / \Delta^{33} S$ slope of -0.9 to -1.5 like most of the Archean-early Paleoproterozoic data 29,44 or negatively correlated $\Delta^{36} S / \Delta^{33} S$ from ice core data ${ }^{16-}$ $18,45,46$ (Fig. 4). This may be due to the limited number of multiple S-isotope analysis as our S-MIF data were measured from a single section. There are Archean-early Paleoproterozoic multiple S-isotopic data that show marked $\Delta^{33} \mathrm{~S}$ anomalies but with limited $\Delta^{36} \mathrm{~S}$ variation, like the S-MIF at Honghuayuan (Fig. 4). Though the exact underlying mechanisms to produce the S-MIF are debated, all the Archean-early Paleoproterozoic and modern stratospheric volcanic sulphate data with large $\Delta^{33} S$ anomalies have been ultimately linked to photochemical reactions ${ }^{16-20,28,44-47}$. There is little reason to assume that this would not be the case for our Late Ordovician S-MIF. Photochemical experiments have shown that $\Delta^{33} S-\Delta^{36} S$ patterns are highly dependent on photochemical conditions, yielding various $\Delta^{36} \mathrm{~S} / \Delta^{33} \mathrm{~S}$ slopes from -4.9 to 4.9 (Fig. 4 ). The large $\Delta^{33} \mathrm{~S}$ anomalies with or without distinct relationships with $\Delta^{36} S$ suggest that the volcano-atmosphere interaction in the Late Ordovician was possibly different than today, or that they might also reflect changing physical and chemical pathways for transporting and production of aerosol sulphate in the atmosphere.

Collectively, we find little evidence of TSR at Honghuayuan, and our data are inconsistent with the isotopic signals from the experimental results of TSR. There is no S-MIF example produced by TSR alone from rock record that is comparable to the S-MIF at Honghuayuan. Rather, our large $\Delta^{33} S$ anomalies are comparable to the $\Delta^{33} S$ found in ice core sulphate and attributed to stratospheric volcanism, which likely resulted from 


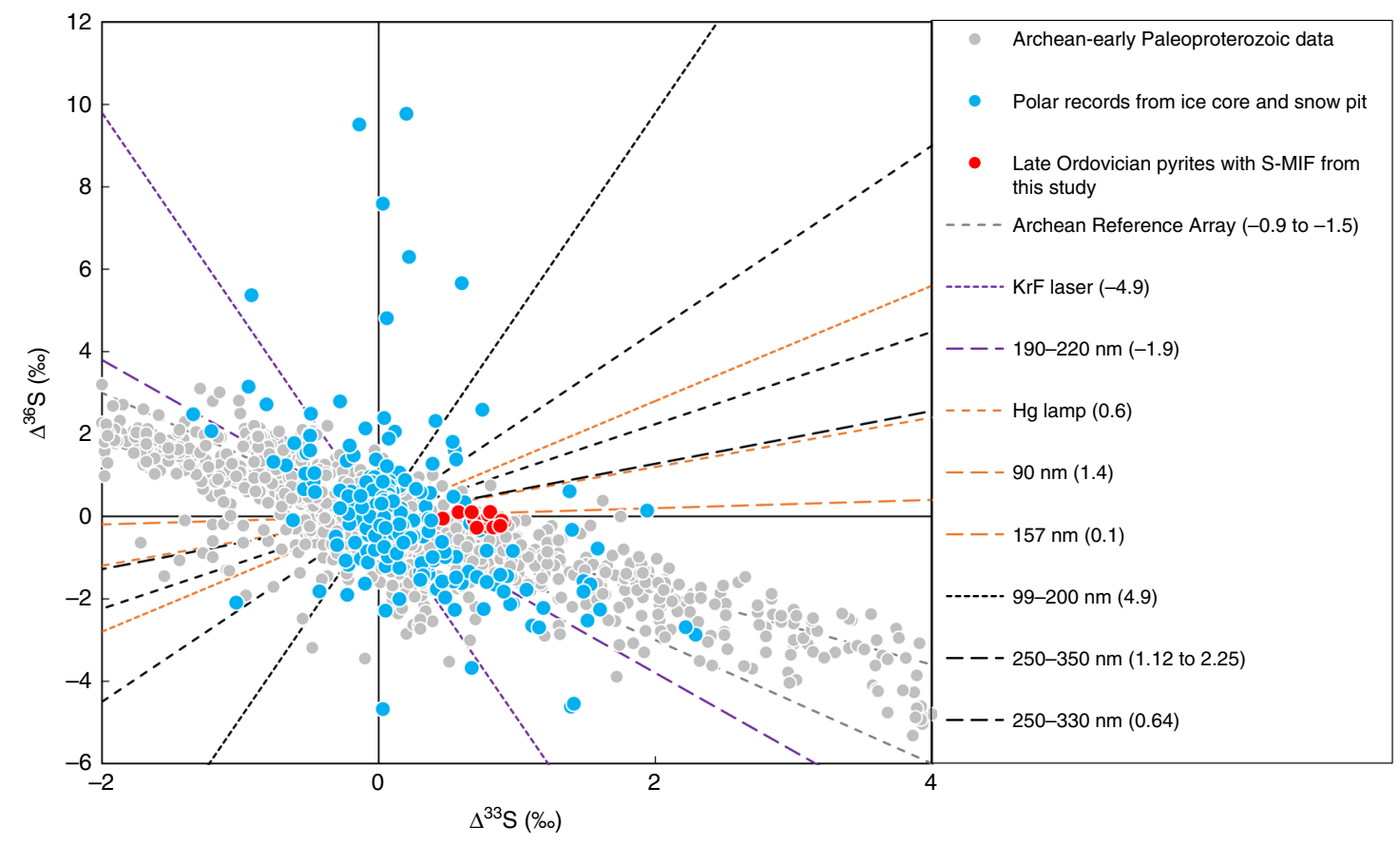

Fig. 4 Mass-independent S-isotope effects observed in rock and polar record. The Archean-early Paleoproterozoic rock record (filled grey circles) are compiled from refs. 27,28,30,31,44,47, and the polar record from ice core and snow pits (filled blue circles) are from refs. $16-18,45,46,49$. The Late Ordovician rock record (filled red circles) are from this study. The two dotted grey lines illustrate the Archean Reference Array $\left(\Delta^{36} \mathrm{~S} / \Delta^{33} \mathrm{~S}=-0.9\right.$ to -1.5$)$ and the $\Delta^{36} \mathrm{~S} / \Delta^{33} \mathrm{~S}$ slopes of photochemistry experiments are compiled from refs. 44,47 , and references therein.

photochemical reactions involving sulphur species in the stratosphere at or above the ozone layer ${ }^{16-20}$.

The atmospheric $\mathrm{O}_{2}$ during the Late Ordovician was estimated to have contained $\sim 17-30 \%$ of present atmospheric levels ${ }^{48}$, which is far more than that prior to the GOE, $\sim 2$ billion years earlier ${ }^{28,30}$. Therefore, the interpretation for the S-MIF observed in the Honghuayuan section requires a mechanism to generate $\mathrm{S}$ MIF in the presence of atmospheric oxygen. The S-MIF data observed in modern stratospheric volcanic sulphate aerosols have been attributed to photochemical reactions in the upper atmosphere ${ }^{16-20,45}$. These observations demonstrate that the production, transport, and preservation of S-MIF signals can occur in an oxidising atmosphere. The S-MIF signals in modern volcanic sulphate aerosols are exclusively linked with violent stratospheric eruptions that have sufficient energy to inject volcanic materials into the stratosphere at or above the ozone layer where short wavelength $\mathrm{UV}(\lambda<300 \mathrm{~nm})$ radiation is available. As such, the SMIF has been used as an important tool to trace stratospheric eruptions in the past ${ }^{16-20,46,49}$.

We suggest that the Late Ordovician S-MIF signals from South China may be best explained by a similar mechanism to modern stratospheric volcanic sulphate aerosols. Our data suggest an atmospheric sulphur cycle that begins with volcanic injections of large amounts of $\mathrm{S}$-bearing gases probably dominated by $\mathrm{SO}_{2}$ (ref. ${ }^{50}$ ) into the stratosphere, at or above the ozone layer, where the UV flux is high (Fig. 5). The subsequent photochemical reactions of the volcanogenic $\mathrm{SO}_{2}$ produce mass-independently fractionated sulphate aerosols with positive $\Delta^{33} \mathrm{~S}$ anomalies similar to modern stratospheric volcanic sulphate aerosols ${ }^{16-20,45,46,49}$.

Following the transfer of the Late Ordovician stratospheric sulphate aerosols to Earth surface environments like Honghuayuan, atmospherically derived sulphate aerosols would mix with dissolved seawater sulphate in the local environment (Fig. 5). This mixed sulphate pool may then produce sulphide through MSR, which is solely a mass-dependent process (Fig. 5). As a result, the sulphide produced through this MSR is mass- dependently isotopically fractionated with respect to the parent sulphate, with the produced sulphide depleted in ${ }^{34} \mathrm{~S}$, preserved in pyrite (Figs. 3 and 5). We note that all pyrite samples with the SMIF compositions from Honghuayuan exhibit a tight linear array parallel to the MFL, originating from microbial reduction of sulphate with a S-MIF composition (Fig. 3).

In contrast to the Honghuayuan section, none of pyrite samples from the XY5 core exhibit a S-MIF composition. Rather, they show limited $\Delta^{33} S$ variation from $0.04 \%$ to $0.16 \%$, suggesting they result from S-MDF process, even though the Kbentonite beds are widespread in both $\operatorname{areas}^{24}$ (Fig. 1a, b). The significant differences in the S-isotopic compositions may reflect the difference in the depositional environment between the Honghuayuan section and that in the XY5 core. The Honghuayuan section was deposited in an innermost sub-basin near to land, where water exchange with the open ocean was quite restricted during the Late Ordovician ${ }^{21}$ (Fig. 5). The Honghuayuan section samples contain extremely low total sulphur content with an average of $0.07 \%$ and TS/TOC (total sulphur/ total organic carbon) ratios with an average of 0.01 that are similar to those found in typical freshwater environments ${ }^{51}$, which usually contain orders-of-magnitude less sulphate than in normal marine environments (Fig. 6). The extremely low TS/ TOC in the Honghuayuan section is consistent with our hypothesis that the major dissolved sulphate in this area was supplied atmospherically. By contrast, the XY5 core section was deposited in a relatively deep-water environment and the XY5 core samples are characterised by high total sulphur content of up to $7.75 \%$ and TS/TOC ratios of up to 5.67 that are consistent with marine conditions, which typically contains much higher sulphate than freshwater environment (Fig. 6). We suggest that the relatively high sulphur concentration and large pool of dissolved seawater sulphate where the XY5 core was deposited may have isotopically homogenised the atmospherically derived sulphate, producing sulphide with S-MDF compositions as we observe (Fig. 1b). 


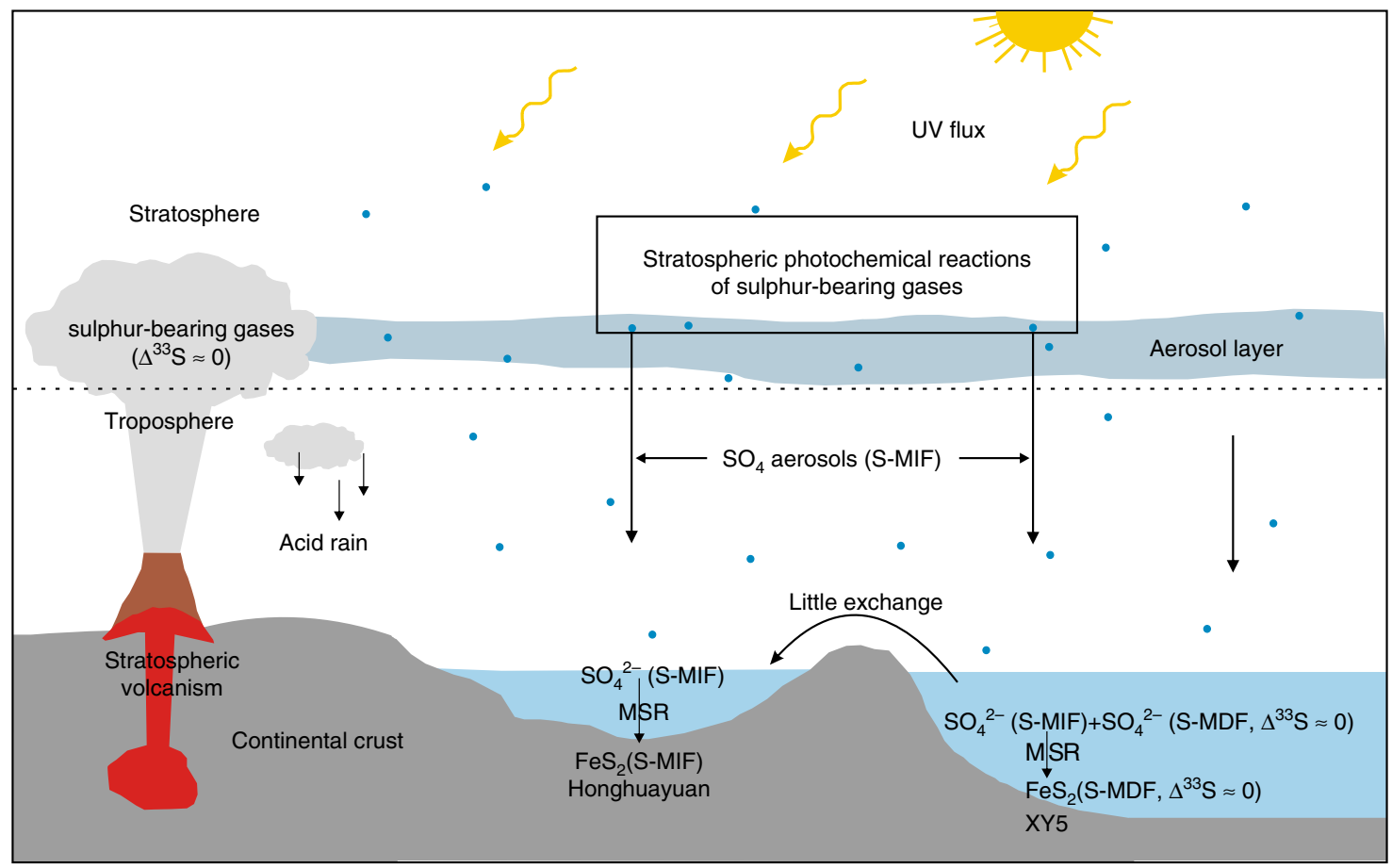

Fig. 5 Proposed sulphur cycle for the observed isotope record. UV: ultraviolet, S-MIF: S-isotope mass-independent fractionation, S-MDF: S-isotope massdependent fractionation, MSR: microbial sulphate reduction.

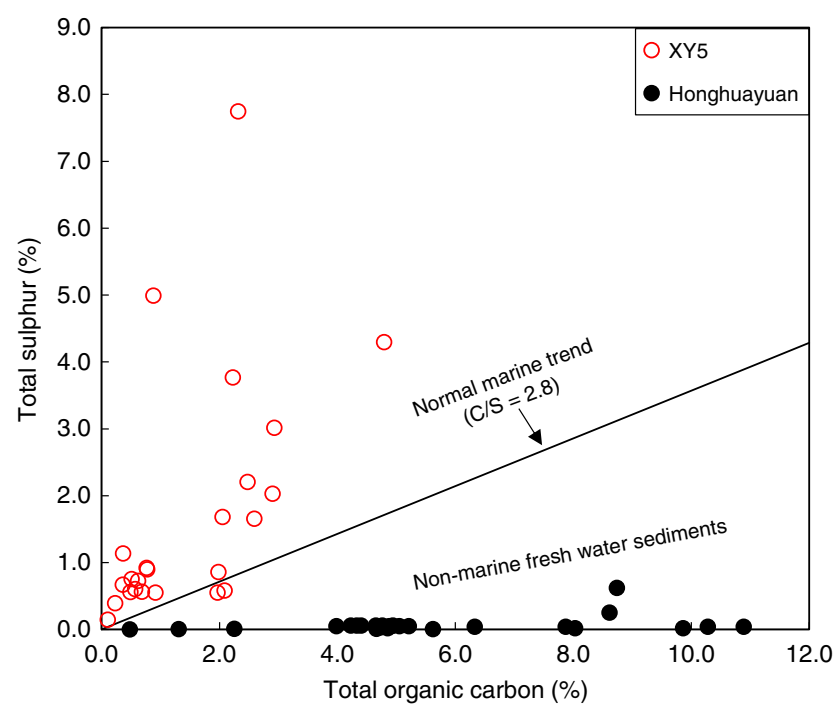

Fig. 6 Cross-plot of total organic carbon and total sulphur. Filled black circles are from Honghuayuan, and red circles are from XY5. Black solid line represents the typical $\mathrm{C} / \mathrm{S}$ ratio of $\sim 2.8$ for normal marine sediments ${ }^{51}$.

Implications for the Late Ordovician mass extinction. The presence of stratospheric volcano-generated S-MIF data in the Late Ordovician sedimentary rocks from South China may provide new insight into the causes of the LOME. The stratospheric eruptions may have much more severe and prolonged impacts on atmospheric and ocean chemistry, terrestrial environments, and climate change than tropospheric eruptions ${ }^{52-55}$. We note that, based on $\mathrm{Hg}$ abundances and $\mathrm{Hg} / \mathrm{TOC}$ ratios, a LIP event has been hypothesised as a driver for the $\mathrm{LOME}^{13,14}$. However, $\mathrm{Hg}$ enrichments were interpreted to have been sulphide-hosted rather than of volcanic origin, which is against the causal linkage between the LOME and volcanism ${ }^{15}$. Also, there is a lack of geological evidence for a Late Katian-Hirnantian LIP $^{13}$ and the nature of the volcanic eruptions such as the explosivity and specifically, if the volcanic plumes penetrated the stratosphere remains poorly constrained. The nature of volcanic eruptions is critical because volcanic sulphur-induced climate change such as cooling or sulphuric acid-driven ocean acidification cannot cause a profound biotic crisis unless eruptions occurred with high intensity and over long durations owing to the buffering capacity of the Earth system ${ }^{56}$.

In this study, the S-MIF data from South China provide evidence for stratospheric volcanic eruptions during the Late Ordovician that were coincident with the first pulse of the LOME (Fig. 1a). Kill mechanisms and environmental perturbations stemming directly from the stratospheric volcanic eruptions may include sulphur-induced climate cooling, acid rain and ocean acidification from emission of $\mathrm{SO}_{2}$ and $\mathrm{CO}_{2}$, toxic metal poisoning, and anoxia associated with release of $\mathrm{CO}_{2}$ and other greenhouse gases as well as enhanced delivery nutrients to the ocean ${ }^{52-58}$. Sulphur species (mainly $\mathrm{SO}_{2}, \mathrm{H}_{2} \mathrm{~S}, \mathrm{COS}$ ) are the primary volcanic volatiles known to impact climate directly, as their oxidation to $\mathrm{H}_{2} \mathrm{SO}_{4}$ in the atmosphere forms sulphate aerosols that disturb the atmospheric radiation balance ${ }^{52-55}$. In the troposphere, volcanogenic sulphur is rapidly oxidised to sulphate and washed out of the atmosphere ${ }^{52-54}$. The climate perturbations by the emission of sulphur are greatest when sulphur species are ejected into the stratosphere, where they react mainly with $\mathrm{OH}$ and $\mathrm{H}_{2} \mathrm{O}$ to form sulphate aerosols ${ }^{52-55}$. The stratospheric sulphate aerosols can play a critical role in Earth's heat budget because they may backscatter incoming short-wave solar radiation and absorb outgoing long-wave radiation, leading to global cooling at the Earth's surface ${ }^{52-55}$. Though climate cooling resulting from modern individual stratospheric volcanic eruptions may be relatively short, explosive stratospheric volcanic eruptions in the geological past could have prolonged and profound climatic ramification ${ }^{59}$. The S-MIF data we observe suggest that explosive and sustained stratospheric volcanic eruptions during the Late Ordovician could have potentially 
contributed to the icehouse conditions, coupled with $p \mathrm{CO}_{2}$ drawdown through enhanced silicate weathering and organic carbon burial ${ }^{60,61}$, though much remains enigmatic on the climatic feedback of particularly the early Hirnantian. Additional kill mechanisms for the LOME may be linked to expansion of oceanic anoxia, which has been inferred from isotopic and elemental proxies coincident with the $\mathrm{LOME}^{9-12}$. Hence, our Sisotopic data suggest that stratospheric volcanic eruptions during the Late Ordovician may have contributed to the synergetic environmental deteriorations such as global climatic perturbations from volcanic sulphur and $\mathrm{CO}_{2}$ release, ocean anoxia and acidification, and ecosystem poisoning, which may have driven the first pulse of the LOME. However, we find no evidence of the S-MIF signals during the second pulse of the LOME at Honghuayuan (Fig. 1a), suggesting little role of the stratospheric volcanism in the second pulse of the LOME.

Numerous K-bentonites beds of Ordovician-Silurian age have been identified worldwide, which probably record intensified volcanic eruptions ${ }^{62}$. Integrated with well-established biostratigraphy, precise dating of each pulse of the LOME, and sedimentary facies, the quadruple sulphur isotope measurements on Ordovician-Silurian rocks, especially terrestrial sedimentary rocks, can be used to test our hypothesis and improve our understanding of global climate change and its causal relationships with the LOME. Our study demonstrates that the use of quadruple sulphur isotopes is an important tool to explore atmospheric and ocean chemistry changes related to volcanic eruptions and their potential links to the biological evolution.

\section{Methods}

Pyrite extraction, total sulphur and total organic carbon measurement. Pyrite was extracted with the Cr-reduction method and the sample powders were reacted with a solution of $6 \mathrm{~N} \mathrm{HCl}$ and reduced chromium chloride $(\mathrm{Cr}(\mathrm{II}))$ at $\sim 80^{\circ} \mathrm{C}$. The reaction proceeded for $\sim 2$ hours to liberate hydrogen sulphide, which was driven by a flow of nitrogen gas through a water-cooled condenser and a bubbler filled with Milli-Q water, and then quantitatively precipitated as silver sulphide $\left(\mathrm{Ag}_{2} \mathrm{~S}\right)$ by reacting with silver nitrate solution. TS and TOC were measured by a CS-902T high-frequency infra-red carbon-sulphur analyzer. The bulk and decarbonated powdered samples were weighed and combusted in an oxygen atmosphere by an induction furnace. The TS and TOC contents were determined by the infra-red detector, yielding analytical uncertainties of $\pm 3 \%$ and $\pm 0.5 \%$ of reported values, respectively.

Sulphur isotopic analyses. Multiple S-isotope analyses followed the published procedures ${ }^{29,33}$. $\mathrm{Ag}_{2} \mathrm{~S}$ was fluorinated with a $\times 10$ excess of $\mathrm{F}_{2}$ at $\sim 250^{\circ} \mathrm{C}$ overnight in a $\mathrm{Ni}$ reaction vessel. The product $\mathrm{SF}_{6}$ was isolated from the residual $\mathrm{F}_{2}$ into a liquid-nitrogen cooled trap, distilled at $\sim-110^{\circ} \mathrm{C}$ from condensable contaminants and then further purified by a gas chromatograph equipped with a composite molecular sieve $5 \AA$ lead/Haysep-Q column. S-isotope compositions of the clean $\mathrm{SF}_{6}$ were measured using a ThermoFinnigan MAT 253 gas source mass spectrometer where the ion beams at $m / z=127,128,129$ and 131 were detected simultaneously. Isotope data are reported in \%o relative to Vienna Canyon Diablo Troilite. The uncertainties were assessed by repeated fluorination and measurements of a reference material of IAEA S1 and are estimated to be better than $\pm 0.2 \%, \pm 0.01 \%$ and $\pm 0.2 \%$ for $\delta^{34} S, \Delta^{33} S$ and $\Delta^{36} S$, respectively. The XY5 samples were measured at University of Science and Technology of China, and the Honghuayuan samples were measured at the University of Maryland (UMD).

Inter-laboratory measurements. Three samples from Honghuayuan were reanalysed at Institut de Physique du Globe de Paris (IPGP), France using the same method of pyrite extraction, fluorination of $\mathrm{Ag}_{2} \mathrm{~S}$ and measurement of S-isotope compositions as that of UMD. As shown in Supplementary Table 3, the measurements at IPGP reproduce reasonably well the S-isotope values from UMD.

Equivalent vitrinite reflectance. The samples were prepared to be a polished petrographic mount with a flat and smooth surface suitable for microscopy. The maceral observation and random graptolite reflectance measurements were conducted using a Leica reflected light microscope equipped with a CRAIC microscope photometer. The reflectance measurements were taken at $546 \mathrm{~nm}$ wavelength in oil immersion, after calibrating the microscope against two internal standards. A total of $\sim 40$ such measurements were performed per sample. The equivalent vitrinite reflectance (Ro) values were then calculated from the mean random graptolite reflectance (GRo) on the basis of the conversion equation: $\mathrm{Ro}=0.8 \times$ GRo (ref. ${ }^{63}$ ).

\section{Data availability}

All data reported in this study are available in Supplementary Tables 1-4.

Received: 22 May 2019; Accepted: 17 April 2020;

Published online: 08 May 2020

\section{References}

1. Sheehan, P. M. The Late Ordovician mass extinction. Annu. Rev. Earth Planet. Sci. 29, 331-364 (2001).

2. Melchin, M. J., Mitchell, C. E., Holmden, C. \& Storch, P. Environmental changes in the Late Ordovician-early Silurian: Review and new insights from black shales and nitrogen isotopes. Geol. Soc. Am. Bull. 125, 1635-1670 (2013).

3. Brenchley, P. J. et al. Bathymetric and isotopic evidence for a short-lived Late Ordovician glaciation in a greenhouse period. Geology 22, 295-298 (1994).

4. Brenchley, P. J. et al. High-resolution stable isotope stratigraphy of upper Ordovician sequences: constraints on the timing of bioevents and environmental changes associated with mass extinction and glaciation. Geol. Soc. Am. Bull. 115, 89-104 (2003).

5. Saltzman, M. R. \& Young, S. A. Long-lived glaciation in the Late Ordovician? Isotopic and sequence-stratigraphic evidence from western Laurentia. Geology 33, 109-112 (2005).

6. Finnegan, S. et al. The magnitude and duration of Late Ordovician-early Silurian glaciation. Science 331, 903-906 (2011).

7. Ghienne, J. F. et al. A Cenozoic-style scenario for the end-Ordovician glaciation. Nat. Commun. 5, 4485 (2014).

8. Creveling, J. R., Finnegan, S., Mitrovica, J. X. \& Bergmann, K. D. Spatial variation in Late Ordovician glacioeustatic sea-level change. Earth Planet. Sci. Lett. 496, 1-9 (2018).

9. Zhang, T., Shen, Y., Zhan, R., Shen, S. \& Chen, X. Large perturbations of the carbon and sulfur cycle associated with the Late Ordovician mass extinction in South China. Geology 37, 299-302 (2009).

10. Yan, D., Chen, D., Wang, Q. \& Wang, J. Predominance of stratified anoxic Yangtze Sea interrupted by short-term oxygenation during the Ordo-Silurian transition. Chem. Geol. 291, 69-78 (2012).

11. Hammarlund, E. U. et al. A sulfidic driver for the end-Ordovician mass extinction. Earth Planet. Sci. Lett. 331-332, 128-139 (2012).

12. Bartlett, R. et al. Abrupt global-ocean anoxia during the Late Ordovician-early Silurian detected using uranium isotopes of marine carbonates. Proc. Natl Acad. Sci. USA 115, 5896-5901 (2018).

13. Jones, D. S., Martini, A. M., Fike, D. A. \& Kaiho, K. A volcanic trigger for the Late Ordovician mass extinction? Mercury data from south China and Laurentia. Geology 45, 631-634 (2017).

14. Gong, Q. et al. Mercury spikes suggest volcanic driver of the OrdovicianSilurian mass extinction. Sci. Rep. 7, 5304 (2017).

15. Shen, J. et al. Mercury in marine Ordovician/Silurian boundary sections of South China is sulfide-hosted and non-volcanic in origin. Earth Planet. Sci. Lett. 511, 130-140 (2019).

16. Savarino, J., Romero, A., Cole-Dai, J., Bekki, S. \& Thiemens, M. H. UV induced mass-independent sulfur isotope fractionation in stratospheric volcanic sulfate. Geophys. Res. Lett. 30, 2131 (2003).

17. Baroni, M., Thiemens, M. H., Delmas, R. J. \& Savarino, J. Mass-independent sulfur isotopic compositions in stratospheric volcanic eruptions. Science 315, 84-87 (2007)

18. Baroni, M., Savarino, J., Cole-Dai, J., Rai, V. K. \& Thiemens, M. H. Anomalous sulfur isotope compositions of volcanic sulfate over the last millennium in Antarctic ice cores. J. Geophys. Res. 113, D20112 (2008).

19. Gautier, E. et al. 2600-years of stratospheric volcanism through sulfate isotopes. Nat. Commun. 10, 466 (2019).

20. Burke, A. et al. Stratospheric eruptions from tropical and extra-tropical volcanoes constrained using high-resolution sulfur isotopes in ice cores. Earth Planet. Sci. Lett. 521, 113-119 (2019).

21. Wang, K. et al. The great latest Ordovician extinction on the South China Plate: chemostratigraphic studies of the Ordovician-Silurian boundary interval on the Yangtze platform. Palaeogeogr. Palaeoclimatol. Palaeoecol. 104, 61-79 (1993).

22. Chen, X. et al. Late Ordovician to earliest Silurian graptolite and brachiopod biozonation from the Yangtze region, South China, with a global correlation. Geol. Mag. 137, 623-650 (2000).

23. Zeng, Q. L. Ordovician brachiopod communities and eustatic changes of sealevel in the eastern Yangtze Gorges area. Bull. Yichang Inst. Geol. Miner. Resour. Chin. Acad. Geol. Sci. 16, 13-39 (1991). 
24. $\mathrm{Su}, \mathrm{W}$. et al. K-bentonite, black-shale and flysch successions at the Ordovician-Silurian transition, South China: possible sedimentary responses to the accretion of Cathaysia to the Yangtze Block and its implications for the evolution of Gondwana. Gondwana Res. 15, 111-130 (2009).

25. Ge, X. et al. Mineralogical and geochemical characteristics of K-bentonites from the Late Ordovician to the Early Silurian in South China and their geological significance. Geol. J. 54, 514-528 (2018).

26. Hulston, J. R. \& Thode, H. G. Variations in the $S^{33}, S^{34}$, and $S^{36}$ contents of meteorites and their relation to chemical and nuclear effects. J. Geophys. Res. 70, 3475-3484 (1965).

27. Farquhar, J. \& Wing, B. A. Multiple sulfur isotopes and the evolution of the atmosphere. Earth Planet. Sci. Lett. 213, 1-13 (2003).

28. Farquhar, J., Bao, H. M. \& Thiemens, M. Atmospheric influence of Earth's earliest sulfur cycle. Science 289, 756-758 (2000).

29. Farquhar, J., Savarino, J., Airieau, S. \& Thiemens, M. H. Observation of wavelength-sensitive mass-independent sulfur isotope effects during $\mathrm{SO}_{2}$ photolysis: Implications for the early atmosphere. J. Geophys. Res. 106, 32829-32839 (2001).

30. Thiemens, M. H. History and applications of mass-independent isotope effects. Annu. Rev. Earth Planet. Sci. 34, 217-262 (2006).

31. Paris, G., Adkins, J. F., Sessions, A. L., Webb, S. M. \& Fischer, W. W. Neoarchean carbonate-associated sulfate records positive $\Delta^{33} \mathrm{~S}$ anomalies. Science 346, 739-741 (2014).

32. Torres, M. A., Paris, G., Adkins, J. F. \& Fischer, W. W. Riverine evidence for isotopic mass balance in the Earth's early sulfur cycle. Nat. Geosci. 11, 661-664 (2018).

33. Shen, Y. et al. Multiple S-isotopic evidence for episodic shoaling of anoxic water during Late Permian mass extinction. Nat. Commun. 2, 210 (2011).

34. Zhao, G. \& Cawood, P. A. Precambrian geology of China. Precambr. Res. 222223, 13-54 (2012).

35. Watanabe, Y., Farquhar, J. \& Ohmoto, H. Anomalous fractionations of sulfur isotopes during thermochemical sulfate reduction. Science 324, 370-373 (2009).

36. Oduro, H. et al. Evidence of magnetic isotope effects during thermochemical sulfate reduction. Proc. Natl Acad. Sci. USA 108, 17635-17638 (2011).

37. Barker, C. E. \& Pawlewicz, M. J. Calculation of vitrinite reflectance from thermal histories and peak temperatures: a comparison of methods. In Vitrinite Reflectance as a Maturity Parameter: Applications and Limitations. (eds. P.K. Mukhopadhyay \& W.G. Dow), 216-229 (1994).

38. Goldstein, T. P. \& Aizenshtat, Z. Thermochemical sulfate reduction a review. J. Therm. Anal. 42, 241-290 (1994).

39. Siedenberg, K., Strauss, H., Podlaha, O. \& van den Boorn, S. Multiple sulfur isotopes $\left(\delta^{34} \mathrm{~S}, \Delta^{33} \mathrm{~S}\right)$ of organic sulfur and pyrite from Late Cretaceous to Early Eocene oil shales in Jordan. Org. Geochem. 125, 29-40 (2018).

40. Siedenberg, K., Strauss, H. \& Littke, R. Multiple sulfur isotopes $\left(\delta^{34} S, \Delta^{33} S\right)$ and trace elements (Mo, $\mathrm{U}, \mathrm{V})$ reveal changing palaeoenvironments in the midCarboniferous Chokier Formation, Belgium. Chem. Geol. 441, 47-62 (2016)

41. Machel, H. G. Bacterial and thermochemical sulfate reduction in diagenetic settings-old and new insights. Sediment. Geol. 140, 143-175 (2001).

42. Amrani, A. et al. The sulfur-isotopic compositions of benzothiophenes and dibenzothiophenes as a proxy for thermochemical sulfate reduction. Geochim. Cosmochim. Acta 84, 152-164 (2012).

43. Amrani, A. Organosulfur compounds: Molecular and isotopic evolution from biota to oil and gas. Annu. Rev. Earth Planet. Sci. 42, 733-768 (2014).

44. Ono, S. Photochemistry of sulfur dioxide and the origin of mass-independent isotope fractionation in Earth's atmosphere. Annu. Rev. Earth Planet. Sci. 45, 301-329 (2017).

45. Gautier, E., Savarino, J., Erbland, J. \& Farquhar, J. $\mathrm{SO}_{2}$ Oxidation kinetics leave a consistent isotopic imprint on volcanic ice core sulfate. J. Geophys Res. Atmos. 123, 9801-9812 (2018).

46. Lanciki, A., Cole-Dai, J., Thiemens, M. H. \& Savarino, J. Sulfur isotope evidence of little or no stratospheric impact by the 1783 Laki volcanic eruption. Geophys. Res. Lett. 39, L01806 (2012).

47. Thiemens, M. H. \& Lin, M. Use of isotope effects to understand the present and past of the atmosphere and climate and track the origin of life. Angew. Chem. Int. Ed. Engl. 58, 6826-6844 (2019).

48. Krause, A. J. et al. Stepwise oxygenation of the Paleozoic atmosphere. Nat. Commun. 9, 4081 (2018).

49. Shaheen, R. et al. Large sulfur-isotope anomaly in nonvolcanic sulfate aerosol and its implications for the Archean atmosphere. Proc. Natl Acad. Sci. USA 111, 11979-11983 (2014).

50. Halmer, M. M., Schmincke, H. U. \& Graf, H. F. The annual volcanic gas input into the atmosphere, in particular into the stratosphere: a global data set for the past 100 years. J. Volcanol. Geotherm. Res. 115, 511-528 (2002).

51. Berner, R. A. \& Raiswell, R. Burial of organic carbon and pyrite sulfur in sediments over phanerozoic time: a new theory. Geochim. Cosmochim. Acta 47, 855-862 (1983).
52. McCormick, M. P., Thomason, L. W. \& Trepte, C. R. Atmospheric effects of the Mt Pinatubo eruption. Nature 373, 399-404 (1995)

53. Robock, A. Volcanic eruptions and climate. Rev. Geophys. 38, 191-219 (2000)

54. Mather, T. A. Volcanoes and the environment: Lessons for understanding Earth's past and future from studies of present-day volcanic emissions. J. Volcanol. Geotherm. Res. 304, 160-179 (2015).

55. Kremser, S. et al. Stratospheric aerosol-Observations, processes, and impact on climate. Rev. Geophys. 54, 278-335 (2016).

56. Schmidt, A. et al. Selective environmental stress from sulphur emitted by continental flood basalt eruptions. Nat. Geosci. 9, 77-82 (2015).

57. Grasby, S. E., Sanei, H. \& Beauchamp, B. Catastrophic dispersion of coal fly ash into oceans during the latest Permian extinction. Nat. Geosci. 4, 104-107 (2011).

58. Reiners, P. W. \& Turchyn, A. V. Extraterrestrial dust, the marine lithologic record, and global biogeochemical cycles. Geology 46, 863-866 (2018).

59. Soreghan, G. S., Soreghan, M. J. \& Heavens, N. G. Explosive volcanism as a key driver of the late Paleozoic ice age. Geology 47, 600-604 (2019).

60. Young, S. A., Saltzman, M. R., Foland, K. A., Linder, J. S. \& Kump, L. R. A major drop in seawater ${ }^{87} \mathrm{Sr} /{ }^{86} \mathrm{Sr}$ during the middle Ordovician (Darriwilian): links to volcanism and climate? Geology 37, 951-954 (2009).

61. Swanson-Hysell, N. L. \& Macdonald, F. A. Tropical weathering of the Taconic orogeny as a driver for Ordovician cooling. Geology 45, 719-722 (2017).

62. Huff, W. D. Ordovician K-bentonites: issues in interpreting and correlating ancient tephras. Quat. Int. 178, 276-287 (2008).

63. İnan, S. et al. The Silurian Qusaiba hot shales of Saudi Arabia: an integrated assessment of thermal maturity. Int. J. Coal Geol. 159, 107-119 (2016).

\section{Acknowledgements}

We thank James Farquhar at University of Maryland for providing facility for S-isotope measurement of Honghuayuan section and discussions on the isotopic data, and Pierre Cartigny at Institut de Physique du Globe de Paris, France for analysing three samples (HHY-1, -2, -37) in his laboratory. We thank Boswell A. Wing for inspiring discussions. This study was supported by National Natural Science Foundation of China (41721002, 41520104007, 418908420, 41330102, 41807314), the 111 project and Key Research Programme of Frontier Sciences, Chinese Academy of Sciences (QYZDY-SSWDQC031).

\section{Author contributions}

Y.S. conceived the study; D.H., M.L., X.Z., Y.G. carried out the analyses; D.H. and Y.S prepared the manuscript with inputs from M.L., X.Z., A.V.T. and Y.G.

\section{Competing interests}

The authors declare no competing interests.

\section{Additional information}

Supplementary information is available for this paper at https://doi.org/10.1038/s41467020-16228-2.

Correspondence and requests for materials should be addressed to Y.S

Peer review information Nature Communications thanks the anonymous reviewer(s) for their contribution to the peer review of this work.

Reprints and permission information is available at http://www.nature.com/reprints

Publisher's note Springer Nature remains neutral with regard to jurisdictional claims in published maps and institutional affiliations.

Open Access This article is licensed under a Creative Commons Attribution 4.0 International License, which permits use, sharing, adaptation, distribution and reproduction in any medium or format, as long as you give appropriate credit to the original author(s) and the source, provide a link to the Creative Commons license, and indicate if changes were made. The images or other third party material in this article are included in the article's Creative Commons license, unless indicated otherwise in a credit line to the material. If material is not included in the article's Creative Commons license and your intended use is not permitted by statutory regulation or exceeds the permitted use, you will need to obtain permission directly from the copyright holder. To view a copy of this license, visit http://creativecommons.org/ licenses/by/4.0/.

(c) The Author(s) 2020 